DOI 10.17805/ggz.2017.4.6

\title{
Природа как источник символической деятельности
}

\author{
Л. С. ИМЕННОВА
}

РОССИЙСКАЯ МЕЖДУНАРОДНАЯ АКАДЕМИЯ ТУРИЗМА

Автор рассматривает природу как источник символической деятельности. На протяжении всей истории человечества природа была источником символов, олицетворения, метафоризации. Обусловленные наблюдениями за природой символы использовали поэты, писатели, художники. Они являются непременным атрибутом при создании музейной экспозиции и осмыслении музейного ландшафта.

Ключевые слова: символ; олицетворение; метафора; музей; экспозиция; ландшафт; пространство

\section{Nature as a Source of Symbolic Activities}

\section{S. IMENNOVA \\ RUSSIAN INTERNATIONAL ACADEMY OF TOURISM}

The nature is considered by the author as a source of symbolic activity. Throughout the human history nature has been a source of symbols, impersonation and metaphors. Poets, writers and artists use different natural symbols taken from their nature observations. When people create a museum exhibition and conceptualize a museum landscape, they should take them into account as an essential attribute.

Keywords: symbol; personification; metaphor; museum; exhibition; landscape; space

Общепризнано, что природа являлась «кладовой», «мастерской», объектом приложения усилий человека в создании материальных культурных артефактов (орудия труда, оружие, одежда, жилище, домашняя утварь и т. д.), однако она выступала также объектом символизации (природным предметам и явлениям давалось символическое определение и объяснение), источником символов в мифотворчестве, художественных практиках и т. А. Природа - ресурс не только для практически материальной, но символической, культурной, духовной деятельности.

Аля выживания первобытному человеку необходимо было чувство породненности с природными стихиями и явлениями. Они воспринимались им как родственные себе; физические предметы и явления природы маркировались как живые одушевленные существа, которые необходимо было умилостивить, заговорить, напугать. Такое мировосприятие нашло отражение в мифологии, анимизме, тотемизме, магии.

Природа выступала как фактор культуротворчества. Целые эпохи в развитии мировой культуры прошли под знаком подражания природе (классическая Античность, Раннее Возрождение). В античный период появился один из основных принципов эстетики мимесис, обозначающий подражание искусства природе, действительности. Мировоззренческий принцип природосообразности, основанный на убеждении в том, что существует единство человека с природой и необходимо учитывать природные за- тки человека, был принят в теории воспитания.

Такие категории, как олицетворение, метафоризация стали важными инструментами познания окружающего мира и себя в этом мире. Олицетворение, или персонификация (от лат. persona и facio), или прозопопея (от греч. $\pi \rho \circ \sigma \omega \pi л о 1 \alpha)-$ это свойство мифопоэтического сознания переносить черты живых существ на неодушевленные вещи и явления, изображение неодушевленного предмета или абстрактного понятия как одушевленного (Большой..., 2007: 1887). Можно предположить, что твор- 
ческий прием олицетворения первоначально возник при изображении (и осмыслении) явлений природы: Зевс - громовержец, Гея - земля, Нептун - море и т. п.

В первоначальных мифологических и религиозных представлениях на ранних этапах становления культуры религиозно-мифологические олицетворения выступали в сознании человека для обозначения особого рода природной реальности, а также для ее символического кодирования, как механизм ее объяснения и как канал взаимодействия с ней. Олицетворение как психологическая установка стало одной из предпосылок возникновения религиозных верований; оно является определяющим признаком мифологического повествования. Обращения к олицетворению обусловлены синкретизмом мировосприятия первобытного человека, составной частью которого была невыделенность человека из окружающей природы: «Уподобляя свое реальное существование бытию природных объектов, культура становится формой бытия, приобретает онтологический статус и тем самым, подобно явлениям природы, становится доступной экспериментальному и теоретическому изучению» (Культурология, 2007: 222).

В процессе становления литературы в арсенале поэтов и писателей появляются поэтические олицетворения. Традиционно специфика создания художественных образов, запечатлевающих природные объекты, рассматривалась специализированными искусствоведческими и литературоведческими дисциплинами, однако необходимо обобщающее культурологическое осмысление, которое мы предполагаем сделать на материале жизни и творчества поэта Александра Блока и особенностей создания посвященного ему музея «Шахматово» в Подмосковье.

В жизни великого русского поэта Александра Александровича Блока (1880-1921) подмосковное сельцо Шахматово играло не менее важную роль, чем Петербург. Шахматово было приобретено дедом поэта Андреем Николаевичем Бекетовым (18251902), ученым, ботаником, профессором и ректором Петербургского университета.

Впервые Блока привезли в Шахматово в возрасте полугода весной 1881 г. В детские и юношеские годы он проводил здесь каждое лето, приезжал зрелым поэтом. Около 300 произведений поэта имеют авторскую датировку, позволяющую считать их шахматовскими. Во многих из них своеобразная и поэтичная природа этих мест определила образный строй и тональность стихотворений, узнаются конкретные реалии в окрестностях Шахматова. Сюда приезжали друзья поэта, в том числе летом 1904 и 1905 г. Андрей Белый.

Одним из ярких примеров использование символического ресурса природных объектов дает творчество А. А. Блока. Особое место занимает образ Неопалимой Купины - сложный многоуровневый и многозначный символ природного, библейского, а также биографического ряда. Его называют центральным образом и носителем идеала молодого Блока. Это один из тех узлов метафорической образности, который связывает не только отдельные стихотворения, но и циклы, книги поэта, обусловливает его самоопределение как в поэзии, так и в жизни.

Уже в самом библейском тексте оказались заложенными возможности существования этого образа в разных, хотя и взаимосвязанных понятийных рядах, что делало христианскую образность особенно привлекательной для символистов. В библейском сюжете пророк Моисей пас стадо в пустыне и у горы Хорив увидел Купину - терновый куст, горящий и не сгорающий. Из куста он услышал голос Божий - повеление идти к фараону и добиваться освобождения израильтян.

Одна из почитаемых икон Божией Матери имеет то же название, ее символика предопределена ветхозаветным преданием: пророк Моисей видел в Купине прообраз 
Богоматери, которая горит и не сгорает. Пространство иконы организуют два наложенных друг на друга четырехугольника: красный символизирует огонь Купины, зеленый - природный цвет несгорающего куста. Изо всех образов Богоматери Неопалимая Купина наиболее «светоносный», воплощающий природные идеи света, огня, растения (куста).

Блоковский образ - своеобразная «сборная цитата», в которой можно отметить аллюзии, отсылающие к творчеству поэтов-современников (например, к стихотворению Вл. Соловьева «Неопалимая Купина», цитата из которого использована Блоком в качестве эпиграфа к одному из стихотворений). Наиболее полно символ реализуется в стихотворении периода страстного увлечения $\Lambda$. А. Менделеевой (1902 г.) «Странных и новых ищу на страницах...» (Блок, 1997: 102).

Многоплановость образа реализуется в двух смысловых пластах: Купина - священный неопалимый терновый куст («Терны венчают смиренных и мудрых / Белым огнем Купины») и Аева-Купина («Тайно тревожна и тайно любима / Аева, Заря, Купина»). Стихотворение как бы вневременное, действие происходит в «оторванный миг» вечности. Сопричастность огню - божественный дар, но белый огонь Купины венчает терном, это испытание, крест, но и высшая награда. Аостаточно явны черты реальной девы - возлюбленной: «Белая Ты, в глубинах несмутима, / В жизни - строга и гневна. / Тайно тревожна и тайно любима». Одним именем Купины объединены - и этим соотнесены - Аева-Купина и Моисеев Куст - Купина как источник божественного дара. Появление «Аевы, Зари, Купины» воспринимается лирическим героем как «божественный дар».

Образ, созданный с отсылкой на предмет природного ряда (растение, куст), наполняется многозначной библейско-религиозной символикой; затем в последующей интерпретации соотносится Блоком с образным рядом, характерным для поэтов-символистов, свойственным их мироощущению. Поскольку образ Купины сквозной, находящий воплощение в других стихах, в творческой лаборатории Блока он наполняется конкретикой природных реалий лета 1902 г. (красные зори и шахматовские пейзажи), тем самым возвращается к природным истокам, окрашивается любовным чувством поэта к $\Lambda$.А. Менеделеевой.

Семантическое поле образной системы стихотворения строится по принципу сопротивопоставления, на одновременном проецировании и взаимодействии нескольких взаимообусловленных общекультурных и индивидуально стилистических полей: Неопалимая Купина - образ «природного» ряда, христианский (библейский) код, код иконы Богоматери Неопалимая Купина, код символизма, индивидуальный поэтический код А. Блока: «Отрицающее не уничтожает отрицаемого, а вступает с ним в отношение сопротивопоставления» (Иотман, 1998: 237).

Шахматово, может быть, как никакое другое место, давало возможность ощутить себя в неразрывной связи с зорями, огнями, лесами, полями. В смысловом наполнении символа Купины выходят на первый план «природные» черты, она становится знаком, метафорой природы.

В «мистическом ключе» сквозь призму поэзии А. А. Блока воспринял Шахматово один из первых паломников в эти поэтические места, тоже поэт Андрей Белый: «Мистическое настроение окрестностей Шахматова таково, что здесь чувствуется как бы борьба, исключительность, напряженность, чувствуется, что зори здесь вырисовываются иные среди зубчатых вершин лесных гор, чувствуется, что и сами леса, полные болот и болотных окон, куда можно провалиться и погибнуть безвозвратно, населе- 
ны всякой нечистью... В Блоке чувствовалась связанность с землею, с пенатами здешних мест. Сразу было видно, что в этом поле, саду, лесу он рос и что природный пейзаж - лишь продолжение его комнаты, что шахматовские поля и закаты - вот подлинные стены его рабочего кабинета, а великолепные кусты никогда мною не виданного ярко-пунцового шиповника с золотой сердцевиной - вот подлинная стилистическая рама его благоухающих строчек» (Белый, 1980: 271, 275).

Шахматовский дом сгорел летом 1921 г. В это же лето скончался поэт Александр Блок. В 1960-е годы в блоковские места потянулись почитатели поэта. 9 августа 1970 г., в год, когда отмечалось 90-летие со дня рождения поэта, на шахматовской поляне состоялся первый Блоковский праздник поэзии. Отреставрированный шахматовский дом открылся для посетителей лишь 5 августа 2001 г. В течение нескольких десятилетий шахматовская природа была единственным источником притяжения почитателей поэта.

Соотнесенность творчества поэта, писателя с местами, в которых они жили, несомненна. По мнению И. В. Зорина, природные ландшафты и культурные объекты, в которых характер освоения имеет вторичное значение, а на первый план выходит связь с историей, событиями, личностями, художественными произведениями, можно назвать ассоциативными дестинациями: «Здесь культурная составляющая часто представлена не в материальной, а в ментальной форме, по ассоциации с каким-либо феноменом культуры» (Зорин, 2005: 15). Такие комплексы воспринимаются как культурное пространство - как памятные, сакральные места. Обычно они обозначены музейным учреждением. Музейные работники основывают проекты освоения памятных мест в соответствии с образным строем, художественной символикой поэта, писателя.

С особым интересом А. С. Аихачев анализировал идейно-эстетические представления, связанные с созданием и бытованием парков и садов в их причастности поэзии и литературе в целом. Силу и эмоциональное воздействие садов и парков он выводил из их специфической способности «окружать», эмоционально «захватывать» посетителя; в парке, как в особом «интерьере», человек отдается во власть идейно-эстетического воздействия; в них искусство соединено с природой: «Благодаря своей “идеологичности" и эмоциональности сады и парки занимали исключительное место в поэзии Аомоносова, Аержавина, Жуковского, Пушкина, Тютчева, Анненского, Блока, Ахматовой и многих других русских поэтов. Но и обратное: их поэзия обогащала и развивала в свою очередь идеологическое и эмоциональное содержание этих садов и парков, создавая в них и вокруг них целый строй поэтических ассоциаций и эмоциональных наслоений. Мемориальное значение садов и парков, следовательно, не только в том, что они “объясняют" и “комментируют” литературу, но и в том, что они особым образом настраивают посетителей на определенное восприятие: восприятие самого садово-паркового искусства в свете тех поэтических наслоений, которыми они окружены. Ассоциации, возбуждаемые природой, садово-парковым искусством и поэтическими воспоминаниями, сливаются в единый комплекс и создают у посетителя особое поэтическое “возвышение души” (Аихачев, 1991: 97-98).

Эти проблемы решаются в процессе музеефикации памятников - направления «музейной деятельности и охраны памятников, сущность которого - преобразование недвижимых памятников истории и культуры или природных объектов в объекты музейного показа с целью максимального сохранения, выявления их историко-культурной, научной, эстетической ценности и активного включения в современную культуру. Музеефикация памятников предполагает исследование памятника, его консервацию и реставрацию, сохранение или воссоздание художественно-архитектурных 
или историко-бытовых интерьеров, а также природной и культурно-исторической среды, интерпретацию памятника (через музейные экспозиции, выставки, объяснительные тексты, мемориальные доски), организацию условий для его обзора (путем разработки маршрутов осмотра, определения “видовых точек” и смотровых площадок, установки маршрутных указателей)» (Каменецкий, Каулен, 2001: 390).

В 1970-1980-е годы результаты практической деятельности по музеефикации памятников получили теоретическое обобщение. Сформулированы и введены в практику определенные требования, среди которых можно назвать:

- проведение научных исследований по выявлению историко-культурного значения памятника - архитектурной составляющей и природного окружения;

- установка на воссоздание его цельного художественного облика памятника;

- включение в проект музеефикации природной и историко-культурной среды, воспроизведение ее «атмосферы».

Разнообразные памятники исторической музейной реальности объединялись на принципе системности в экспозиции, циклы экспозиций организовывались в универсальный вид литературно-мемориального учреждения - музеи-заповедники, в которых специфическим музейно-литературным осмыслением охвачены все сопричастные писателю элементы материального мира (Арзамасцев, 1989: 66-68).

Аля музеефикации памятника важны не только теоретические сведения из разных наук, но и построение с их учетом систем философских, культурологических, поэтических образов. В основе музейного осмысления памятников архитектуры и садово-паркового искусства положены мифологемы, аллегории, поэтические образы, художественные символы, к созданию которых причастны порой несколько поколений творцов.

Музейный жанр неизбежно требует «сконструированности» музейной әкспозиции, музейной территории. Музей-заповедник стоит в одном ряду с литературным произведением, изобразительным искусством. Обращаясь к прошлому, музей творит свою историческую реальность на основе сохранившихся материальных остатков. В музее достигается аутентичность не как верность материальная, а аутентичность как точность научная, образная, символическая.

Названия близких и дальних сел, деревень, лесов, холмов, дорог стоят под многими стихотворениями, встречаются в записных книжках и письмах Блока: Руново, Тараканово, Аубровки, Боблово, Ивлево, Малиновая Гора, Церковный лес, Прасолово, Рогачевское шоссе. Это блоковское Большое Шахматово, где, по словам поэта, «далеко поет земля, близко слышится песня и подступает к горлу», где живут «корявые, несчастные и забитые люди с допотопными понятиями, сами себя забывшие».

Аля сотрудников музея осмысление поэтической символики А. Блока имеет прикладное значение в создании образной системы экспозиций, в освоении культурных ландшафтов Большого Шахматова, которые представляют собой художественную модель, текст, вторичные моделирующие системы (термин Ю. М. Аотмана). В качестве текстов культурные ландшафты не только передают информацию, но выполняют функцию коллективной памяти, взаимодействия между текстом и подтекстом, под которым можно понимать смысловую, символическую привязку к творчеству А. Блока.

Тест культурных ландшафтов наполнен символикой, строится на многократной и многослойной кодировке, это предопределяет его многозначность, а также невозможность полно и адекватно (тождественно) передать значение при его анализе. При этом одно значение (природное, общекультурное, поэтическое и др.) не отменяет другого, они присутствуют одновременно, музейный посетитель осознает возможность 
Аругих значений, при сохранении уже осмысленных. По определению Ю. М. Аотмана, они «мерцают», создавая «игровой әффект»: «Строго однозначное определение значение художественной модели возможно лишь в порядке перекодировки ее на язык нехудожественных моделирующих систем. Художественная модель всегда шире и жизненнее, чем ее истолкование, а истолкование всегда возможно лишь как приближение. При перекодировке художественной системы на нехудожественный язык всегда остается «непереведенный» остаток - та сверхинформация, которая возможна лишь в художественном тексте» (Иотман, 2002: 77).

Таким образом, культурный ландшафт в музее - это не только облагороженная человеком, «окультуренная» природа; он наполнен смыслами, символами реминисценциями. Понимание культурного ландшафта Большого Шахматова обеспечивается интерпретацией культурного кода. Культурный текст ландшафта обладает глубиной и многоплановой символикой, его части нельзя воспринимать изолированно или в одном измерении. Восприятие ландшафта как текста зависит от кода, применяемого человеком воспринимающим. В музейных обстоятельствах осуществляется не только «реконструирование» прошлого, но и «конструирование», то есть включение элементов культурного и природного наследия в структуру опыта интерпретатора.

\section{СПИСОК АИТЕРАТУРЫ}

Арзамасцев, В. П. (1985) О семантической структуре музейной экспозиции // Музееведение. На пути к музею XXI века : сб. науч. тр. НИИ культуры. М. С. 35-49.

Белый, А. (1980) Воспоминания об Александре Александровиче Блоке // Александр Блок в воспоминаниях современников : в 2 т. М. : Худож. литература. Т. 1. С. 204-322.

Блок, А. А. (1997) Полн. собр. соч. и писем : в 20 т. М. : Наука. Т. 1.990 с.

Большой Российский энциклопедический словарь. (2007) М. : Большая рєсийская энциклопедия.

Зорин, И. В. (2005) Феномен туризма: избранные сочинения. М. : Наука. 552 с.

Каменецкий, И. С., Каулен, М. Е. (2001) Музеефикация памятников // Российская музейная энциклопедия : в 2 т. М. : Прогресс. Т. 2. С. 390.

Культурология (2007) : учебник / под ред. Ю. Н. Солонина, М. С. Кагана. М. : Высш. образование. 566 с.

Иихачев, А. С. (1981) Заметки о реставрации мемориальных парков и садов // Восстановление памятников культуры: Проблемы реставрации. М. : Искусство. С. 95-120.

Иотман, Ю. М. (1998) Об искусстве. СПб. : Искусство-СПб. 704 с.

Аотман, Ю. М. (2002) История и типология русской культуры. СПб. : Искусство-СПб. 768 с.

Аата поступления: 27.07.2017 2.

Именнова Аюбовь Сергеевна - кандидат педагогических наук, доцент кафедры социологии и культурологии Российской международной академии туризма. Адрес: 141420, Московская область, г. Химки, мкр-н Сходня, ул. Октябрьская, 10. Тел./факс: +7 (495) 574-23-00. Эл. адрес: info@rmat.ru

Imanova Lyubov Sergeevna, Candidate of Pedagogy, Associate Professor, Department of Sociology and Culturology, Russian International Academy of Tourism. Postal address: 10 Oktyabrskaya St., micro district Skhodnya, 141420 Khimki, Moscow region, Russian Federation. Tel./fax: +7 (495) 574-23-00. E-mail: info@rmat.ru

\section{Аля иитирования:}

Именнова $\Lambda$. С. Природа как источник символической деятельности [Электронный ресурс]// Горизонты гуманитарного знания. 2017, № 4. URL: http://journals. mosgu.ru/ggz/article/view/581 (дата обращения: дд.мм.гггт). DOI: 10.17805/ggz.2017.4.6 